\title{
Just a Cambridge circus?
}

\section{Sydney}

IN the first case of its kind, the Australian ombudsman is to investigate the Australian National University's appointment procedure, following accusations that a 'Cambridge cabal' unfairly controls the prehistory department at the university. It is alleged that University of Cambridge graduates of archaeology, and their students, have been given a monopoly of tenured positions in the department.

Johan Kamminga, previously visiting fellow in the department of prehistory within the Research School of Pacific Studies, has claimed that the cabal was established in the early 1960s, when the department was established.

According to a report presented by Kamminga to the ombudsman, in the years 1965-87 the proportions of UK students in the prehistory department were 25 per cent of the total intake. "These proportions are six times higher than the equivalent figures for the research school as a whole", Kamminga says.

Work at the school was reviewed in 1978 and then, according to Kamminga, the focus of research was switched, from Papua New Guinea and the Pacific region to Australia's trading partners - Japan and the South-East Asian countries. The school was encouraged to take graduate students from these areas.

But, says Kamminga, the department of prehistory has not done so, even though up to 40 per cent of the graduate students

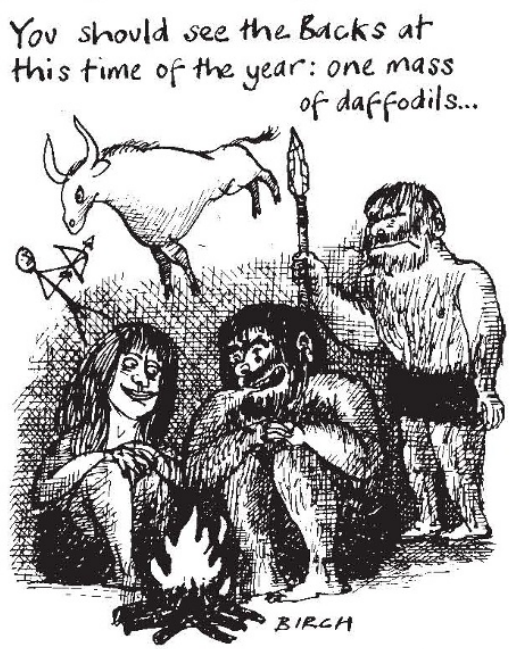

in other departments in the school are from South-East Asia and Japan.

In the latest review, carried out last year, the university recommended that the department canvas more widely in Australia for postgraduate students. "It has been consistently the case, since the early sixties, that the department has fiddled appointments by stacking the selection committees with Cambridge graduates who, in turn, give appointments to other Cambridge graduates. Being
Australian is equivalent to being a black South African. We're allowed to go for junior positions but British graduates get the more senior positions", Kamminga says. Brian Martin, lecturer in the sociology of science and technology at the University of Wollongong, supports Kamminga's claims, describing the department of prehistory as a "Cambridge academic colony down under". Professor Gerard Ward, director of the research school, disputes Kamminga's claims. "There is no preponderance of Cambridge graduates in the prehistory department. Some [Cambridge graduates] were appointed in the early sixties when there were no Australians at that level of seniority. The situation is now different, we have $\mathrm{PhD}$ graduates coming from Australian universities." The one tenured position offered in the department of prehistory in the past ten years was awarded to a candidate with an undergraduate degree from Cambridge.

Professor Dennis Pearce, the Commonwealth ombudsman, says he will investigate the failure of the university to appoint Kamminga to two positions. "I will be concentrating on university appointment procedures. It would be presumptuous of me to second-guess academic appointments or to launch forth on an inquisition of the Cambridge connection", Pearce said. But the ombudsman also says that the allegations of cronyism are relevant to Kamminga's claim that he was unfairly treated. "It may be that we will end up investigating the Cambridge allegations", he said.

Tanla Ewing HUMAN FRONTIER SCIENCE PROGRAM

\section{Turned back at the door}

\section{Sydney \& Tokyo}

Australia, Switzerland, and Sweden, the first non-summit nations to seek membership of Japan's Human Frontier Science Program (HFSP), will have to renegotiate the terms of their entry following a decision made last week by the seven summit nations (Canada, France, United States, Italy, West Germany, the United Kingdom and Japan) and the European Community at a HFSP board of trustees meeting in Strasbourg. But by then Australia may no longer have a budget for the programme.

Frontiers, a Strasbourg-based foundation that supports international research on the brain and molecular biology, was established by Japan in collaboration with the other summit nations. Japan supplies nearly all of the programme's current annual budget of $\$ 15$ to $\$ 20$ million (France and Italy also make small contributions). But all summit nations have an equal say in the running of Frontiers through their representatives on the programme's council of scientists and board of trustees, Frontier's highest governing body.

Switzerland, the first non-summit nation to seek membership, last year offered to contribute $\$ 150,000$ a year in return for one seat on the council of scientists (each summit nation has two seats). Australia and Sweden made similar offers. The Swiss proposal was discussed at the first meeting of the board of trustees last November. But despite enthusiasm from some summit nations, including Japan, representatives of other nations insisted that rules for non-summit membership should first be drawn up (Nature, 342, 601; 1989).

Provisional rules were established at last week's meeting but the board also decided to "re-negotiate" the offers made by the three non-summit countries, according to Toichi Sakata, director of the HFSP office of Japan's Science and Technology Agency. The decision to renegotiate places Australia in an awkward position.

Australia's International Science and Technology Advisory Council (HSTAC) has $\mathrm{A} \$ 285,000$ to promote Australia's attempts to join the Frontier programme, according to Fiona Oliver of the Department for Industry, Technology and Commerce (DITAC). But the money has only been allocated until the end of this financial year (June 30) and ISTAC "is keen to get it out of the coffers by the end of May" in case it has to be returned to general government accounts, Oliver says. However, a decision on Australian membership cannot be made so quickly.

Under the rules drawn up last week, the council of scientists must first judge whether an applicant country is capable of contributing scientifically to the programme. The next council meeting, at which Australian, Swedish and Swiss membership can be discussed, will not be held until the end of May. Then it will be up to the board of trustees to decide an appropriate financial contribution from each country on a "case by case" basis, Sakata says.

If all goes smoothly it is Sakata's "personal hope" that a decision "one way or another" on the three countries can be made by the end of August when STA and the Ministry of International Trade and Industry will finalize their fiscal 1991 budget requests for Frontiers.

Australian government officials are not prepared to comment on the delay until they receive details of last week's meeting from their embassy in Tokyo.

Tanla Ewing \& David Swinbanks 